\title{
Reshaping Literature Through Peritexts: The Case of Esmahan Aykol's Novels in English Translation*
}

\author{
Iç Yanmetinler Aracılığıyla Edebiyatın Yeniden Şekillendirilmesi: Ingilizceye Çevrilen \\ Romanlarında Esmahan Aykol Örneği
}

Research/Araştırma

\author{
Aslı Özlem TARAKÇıOĞLU *, Hümeyra ALTUNTAŞ KIRAN ** \\ * Prof. Dr., Ankara Hacı Bayram Veli University, Faculty of Letters, Translation and Interpreting Studies, \\ asli.tarakcioglu@hbv.edu.tr, ORCID ID: orcid.org/0000-0001-8353- 5526 \\ **Branch Manager, Ministry of National Education, humeyra_altuntas@yahoo.com, ORCID ID: \\ orcid.org/0000-0002-9607-2636
}

\begin{abstract}
The way visual and verbal material surrounding translated literature appear may bear significant implications in relation to the presentation of a foreign text in a receiving literary system, as well as the representation of a whole nation, culture, or literature in the eyes of the receiving one. In the light of this recognition, this descriptive study aims at investigating how the Turkish writer Esmahan Aykol's novels in English translation have been received and presented in the AngloAmerican literary system, as reflected in paratexts. Within this framework, peritextual elements present on the front and back covers of the author's crime novels translated into English and published in the UK and the USA, namely, Hotel Bosphorus, Baksheesh, and Divorce Turkish Style, have been analyzed comparatively with their corresponding material in the source language. The results of the analysis have demonstrated that the city of Istanbul was utilized as the main theme in the presentation of Aykol's novels to the Anglo-American readers, through the selection of book titles, the use of visuals, and/or statements explicitly bringing to light the novels' relatedness with the city. Furthermore, it has been observed that, in some instances, the peritexts of the novels

\footnotetext{
* This article is a part of a PhD dissertation that is being carried out by Hümeyra ALTUNTAŞ KIRAN under the supervision of Assoc. Prof. Dr. Aslı Özlem TARAKÇIOĞLU at Gazi University, Institute of Social Sciences (currently referred to as Ankara Hacı Bayram Veli University, Institute of Graduate Programs), Translation and Interpreting Studies (English) PhD Program.
} 
contained stereotypical or culture-specific elements related to Turkey. In this respect, the analysis has shown that, by contrast with Aykol's discourses displaying a negative stance towards cultural stereotyping, her novels could not escape being exposed to a stereotypical presentation in entering the target literary system. Finally, the findings have revealed how works of literature can be assigned a wholly different image, and thereby destiny in the target system than that assigned in the source system, by virtue of the paratextual translation strategies adopted.

Keywords: Turkish literature in English translation, Esmahan Aykol, paratext, peritext, reception

\section{ÖZET}

Çeviri edebiyat ürünlerini çevreleyen görsel ve yazılı unsurlar, yabancı bir metnin alıcı edebi sistemde ne şekilde sunulduğunun yanı sıra, bir ulusun, kültürün veya edebiyatın alııının nezdinde temsil ediliş biçimine ilişkin önemli anlamlar taşıyabilmektedir. Söz konusu farkındalık ışığında, bu betimsel çalışma ile Türk yazar Esmahan Aykol'un İngilizceye çevrilen romanlarının AngloAmerikan edebi dizgesinde nasıl alımlandığının ve sunulduğunun yanmetinlere yansıdığı şekliyle ele alınması amaçlanmaktadır. Bu çerçevede, yazarın İngilizceye çevrilerek İngiltere ve ABD'de yayımlanan polisiye romanları Kitapçı Dükkânı, Kelepir Ev ve Şüpheli Bir Ölüm'e ait ön ve arka kapaklarda yer alan iç yanmetinsel ögeler, kaynak dildeki karşılıkları ile karşılaştırmalı olarak incelenmiştir. İnceleme sonuçları, Aykol'un romanlarının Anglo-Amerikan okura sunumunda İstanbul'un, kitap isimlerinin seçimi, görsellerin kullanımı ve/veya romanların şehir ile ilintisini açıkça vurgulayan ifadelerin kullanımı yoluyla, ana tema olarak öne çıkarıldığını göstermiştir. Ayrıca, bazı durumlarda, romanlara ait iç yanmetinlerin Türkiye ile ilgili basmakalıp veya kültüre özgü unsurlar içerdiği gözlemlenmiştir. Bu bağlamda çalışma, Aykol'un kültürel basmakalıplaştırmaya yönelik olumsuz bir duruş sergileyen söylemlerinin aksine, yazarın romanlarının erek edebi sisteme girişte basmakalıp bir sunuma maruz kalmaktan kurtulamadığını göstermiştir. Son olarak, bulgular, benimsenen yanmetinsel çeviri stratejileri ile edebi eserlere erek sistemde kaynak sistemde tayin edilenden tamamen farklı bir imaj ve dolayısıyla kader tayin edilebileceğini ortaya koymuştur.

Anahtar Sözcükler: İngilizceye çevrilen Türk edebiyatı, Esmahan Aykol, yanmetin, iç yanmetin, alımlama

\section{Introduction}

It has been well acknowledged for several decades now that translation in general, and literary translation in particular, involves much more than mere linguistic transfer and that translated texts do not stand alone as isolated entities in the receiving system they are attached to. The recognition of the complex and multifaceted nature of translation activity has also paved the way for better recognition of the possibility, and indeed necessity, of dual interaction between translation studies and a wide range of other disciplines. Thus, while scholars from disciplines such as cultural studies have occasionally relied on translation studies to offer new insight into their fields on the one hand, translation studies has in turn borrowed approaches and concepts from different disciplines to better describe translation phenomena by enhancing its borders on the other. One of these borrowed concepts increasingly utilized in translation studies in the last two decades is paratext. 
As put forth by the literary theorist Gerard Genette (1997), the term paratext refers to accompanying material that "surround" and "extend" the text to "present" it, such as the title, the preface, or illustrations (p. 1). Genette makes a further division between two types of paratexts based on their location in relation to their text, namely, peritext and epitext. While peritexts refer to paratextual material physically attached to the text to which they belong like the title, preface, chapter titles, footnotes, and blurbs, epitexts embrace material located outside the book such as reviews, interviews, advertisements, and diaries (pp. 4-5).

It should be noted that, in his book, Genette limits himself to the study of paratextual material present in source texts of literature, i.e., he does not address the issue of the paratexts of translated texts. In fact, Genette regards the translated text as a paratext itself. This positioning of translated literature as a type of paratext in Genette's model, combined with his views on the subordinate and secondary status of paratexts as commentaries of the texts they present, has been, starting with Şehnaz Tahir-Gürçağlar, criticized by several scholars of the discipline for disregarding the principles of contemporary translation studies (see Tahir-Gürçağlar 2002, 2011). However, although its shortcomings in relation to translation research have been acknowledged, pioneered by the articles of Theo Hermans and Urpo Kovala both published in 1996 (Batchelor, 2018, p. 25), Genette's notion of paratext has so far been utilized in many studies of translation approaching the issue from a wide range of perspectives as well as language pairs ${ }^{1}$.

Recently, paratextual material have been the subject of several studies by translation scholars from Turkey as well. To cite some of them, Neslihan Kansu-Yetkiner (2014) examines the peritexts - mainly providing biographical information on the source text authors - of translations of four books appearing on the 100 Essential Readings lists of the Ministry of National Education targeted for young readers in abridged translations to display how the dominant pro-Islamist ideology under which the target texts were produced has been reflected in the peritexts at the expense of significantly distorting the plots of the source texts and rewriting the biographies of their authors. In this sense, the study is a good example demonstrating the highly manipulative power of paratextual material in shaping perceptions regarding the other. Another scholar, Ilgın Aktener (2019), traces the effects of the censorial environment under which the translators in Turkey work - at a time when several publishers and translators were faced with obscenity court cases - in the translator's preface, taking Ahmet Ergenç's preface to the Turkish translation of William S. Burroughs' Exterminator! as a case study. In a similar vein, Lütfiye Oktar and Neslihan Kansu-Yetkiner (2012) inquire the link between discourses formed in translators' prefaces and the social and political climate under which they are produced, taking as their objects of analysis two prefaces penned for the different Turkish translations of a novel which has, since its publication, been subject to discussions in many countries for its obscenity, Lady Chatterley's Lover by D.H. Lawrence, with a focus on the diachronic shifts in discourse arising from the forty-year

\footnotetext{
${ }^{1}$ For information regarding existing research on paratexts in relation to translation studies, see Batchelor (2018, pp. 25-45).
} 
gap between the two prefaces. All these studies, albeit to varying degrees, touch on the ideological nature of translation as reflected in peritexts. In another paper, Gülsüm Canlı and Ayşe Banu Karadağ (2019) explore how the title of William Faulkner's Sanctuary has been rendered into Turkish in its three different translations with a view to shedding light on the reasons underlying the difference in the translated titles of the same novel. While the majority of research from Turkish scholars addresses the paratexts of literary translations into Turkish, a handful of studies are also conducted in recent years that deal with the paratextual presentation of Turkish literature in English translation. For instance, Duygu Tekgül (2011) digs into the representation of literature from the Middle East and Asia in translation in an exoticized manner in the British book market, focusing on the visual peritextual elements existing on the book covers of several translated novels from a selection of source languages including Turkish. On the other hand, Şule Demirkol Ertürk (2019) seeks to exhibit the functions assumed by paratexts in recontextualizing and legitimating a literary masterpiece from Turkey, namely Ahmet Hamdi Tanpınar's Saatleri Ayarlama Enstitüsü, in the Anglophone literary setting, by analyzing the accompanying material of the novel's two translations.

Without doubt, the constantly increasing interest in Genette's model has to do with the recognition of the rich contributions paratextual analyses can make to translation studies. In emphasizing the significance of the paratext for the readers' reception of the text, Genette, citing from Philippe Lejeune $(1975$, p. 45), states that paratext is "a fringe of the printed text which in reality controls one's whole reading of the text" (as cited in Genette, 1997, p. 2), a fringe that aims at "a better reception for the text and a more pertinent reading of it (more pertinent, of course, in the eyes of the author and his allies)" (Genette, 1997, p. 2). When it comes to literature in translation, this authority held by the paratext in the reception and image-formation process is much more functional given that the paratext is, perhaps, the only guide for the reader in approaching an author and a work belonging to a linguistically, culturally, spatially and, maybe even, temporarily different world. Moreover, this distance between the target reader and source text/culture expressly increases the manipulative power of the paratext implied in the above statements, when the paratext in question is the paratext of a translated text. It is well known that, just like texts, paratexts may undergo significant shifts in their translational journey due to, for instance, linguistic, cultural, political, ideological motives or perhaps simply to ensure their text's acceptance in the target system. Thus, borrowing from André Lefevere (1992), it can be asserted that, as material capable of creating "images of a writer, a work, a period, a genre, sometimes even a whole literature" (p. 5), paratexts of translated texts may tell much about the dynamics of translation activity.

In response to the increasing awareness regarding insights paratextual analyses can bring to translation studies, the present study seeks to investigate the reception and presentation of the Turkish writer Esmahan Aykol's novels in English translation as mirrored by their peritexts. Within this framework, the subjects of analysis cover the peritextual material embodied in three crime novels of the author translated into English by Ruth Whitehouse and published in the UK and the USA by Bitter Lemon Press with 
the titles Hotel Bosphorus, Baksheesh, and Divorce Turkish Style. Aykol is among the few Turkish women writers to be available in English translation with more than one novel in the last decade. Besides English, her novels have been translated into many languages and some of them have become best-sellers in the countries they were released (Cornwell, 2011). The fact that the author has secured a place in the international literary scene as one of the representatives of Turkish literature renders her novels as suitable subjects for an analysis on the presentation of Turkish literature in the AngloAmerican literary system. A study centered on Aykol is also significant in that the strategies utilized for her translated novels provide fruitful examples of how works of literature are recreated through peritexts. It is hoped that the present study, involving the analysis of both visual and written peritextual material in a multimodal manner, as distinct from the majority of recent papers from Turkey focusing mainly on written paratexts, will contribute to the field of translation studies.

\section{Methodology}

As mentioned above, the corpus of analysis in this descriptive study comprises peritexts as defined by Genette, i.e., paratextual material physically attached to Aykol's novels subject to analysis. However, considering that Genette's list of peritexts is too lengthy for every item to be addressed in detail in a single article, the analysis is limited with the front and back covers of the books, on the grounds that, as the most immediately visible peritexts, covers assume significant roles in the presentation of a literary work as well as in shaping the reception of the potential reader in a target setting. Both front and back covers of the translations have been analyzed comparatively with their correspondents in the source texts. In this comparison, all editions of the source texts released from different publishing houses have been taken into consideration. While front covers of the translated texts have been presented together with corresponding front covers of their source text editions, the Turkish versions of the back covers have not directly been quoted, yet referred to where deemed necessary in the study, for reasons of space. The results of the comparative analysis of this qualitative data have been used to describe; the manner in which Aykol's novels in English translation are presented to the Anglo-American world by way of paratexts on the one hand, and the extent to which this presentation differs from that of the source texts on the other.

\section{Analysis of the Front Covers}

As the ones encountered first by the potential reader, book covers are perhaps the most important of the thresholds Genette mentions, offering "the world at large the possibility of either stepping inside or turning back" $(1997$, p. 2). In this respect, the peritextual analysis within the framework of this study will begin with the pieces of information - both verbal and non-verbal - contained on the front covers of Esmahan Aykol's novels.

Genette, who classifies the book cover under the heading "The publisher's peritext", provides an exhaustive list of items that may be present on a front cover, including, amongst others, the name and title of the author, the name of the translator, 
and/or of the preface-writer etc., the title of the book, an indication of the genre, dedication, epigraph, illustration, information on the series the book belongs to and information on the publisher (1997, p. 24). In the present study, the analysis regarding front covers will predominantly be concentrated on the decisions taken with respect to the use of illustrations, the rendering of book titles, and the presence of the translator's name.

\subsection{Illustrations}

The cover illustrations selected for the presentation of Akyol's all three novels in the Anglo-American literary system provide us with good examples on the extent of shifts that literature may undergo during its international journey. In fact, just as the old proverb says, an analysis of the visual elements on the book covers reveals that "a picture is worth a thousand words", with regard to how Aykol's novels, and, through these novels, Turkish culture and literature, are represented in the Anglo-American world. The most eye-catching point, at first sight, observed on the front covers of the novels in English translation, is the use of the mosque image, complemented, in most cases, by some other stereotypical image on Turkey.

This kind of occurrence is first seen on the cover of Hotel Bosphorus, the first of the Kati Hirschel murder mystery series written by Aykol. The novel, also being the debut book of the author in English translation, is released in the UK and the USA in 2011. The heroine of the novel, Kati Hirschel, is a German citizen who has lived in Istanbul for many years and is the owner of the only bookshop in the city specializing in crime fiction. When an old friend of hers, the movie actress Petra Vogel, starring in a film, comes to Istanbul and becomes the main suspect in the murder of the film's German director, Kati, as a devoted reader of detective novels and the owner of a crime bookshop, finds herself in trying to solve the crime. It is quite clear from the plot that the novel is produced by the author with the intention of being primarily a murder mystery, and, in fact, is presented as such by Bitter Lemon Press, which has included it under its "Crime and Mystery Fiction" series. Indeed, the fact that the publisher is mainly known for publishing translations of crime novels from various countries further increases the murder mystery attribute of the book. However, an analysis of the English translation reveals that it is not primarily the genre of the novel that is foregrounded on the front cover. Moreover, from a comparison of the front covers of the novel's Turkish versions with that of the English version, it can be observed that the source and translated texts are presented to their respective target audiences from totally different angles: 
Figure 1

The front cover of Kitapçı Dükkânı by Everest Yavınları

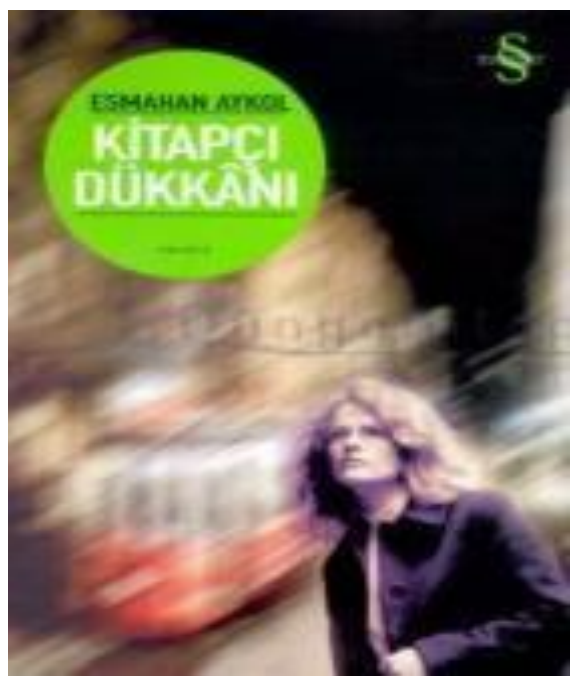

Figure 3

The front cover of Kitap̧̧ı Dükkânı by Eksik Parça

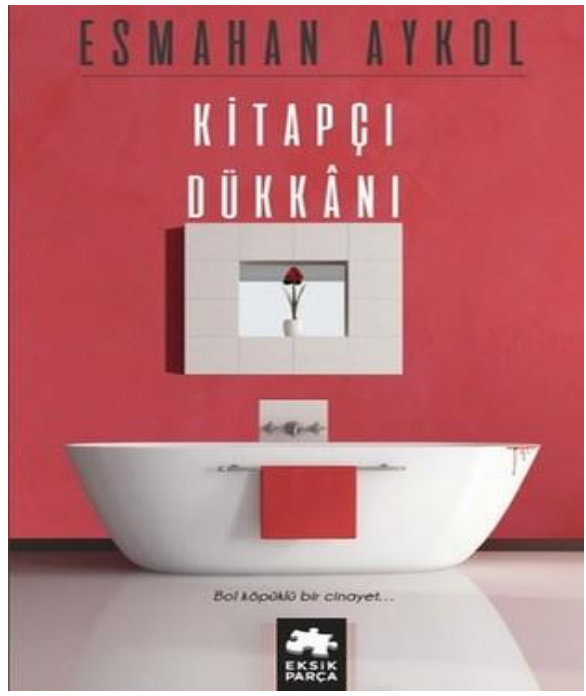

Figure 2

The front cover of Kitapçı Dükkânı by Merkez Kitaplar

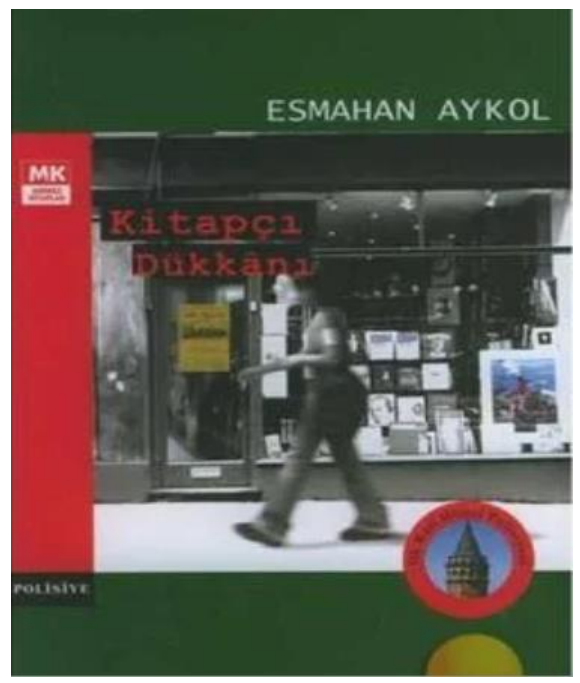

\section{Figure 4}

The front cover of Hotel Bosphorus by Bitter Lemon Press

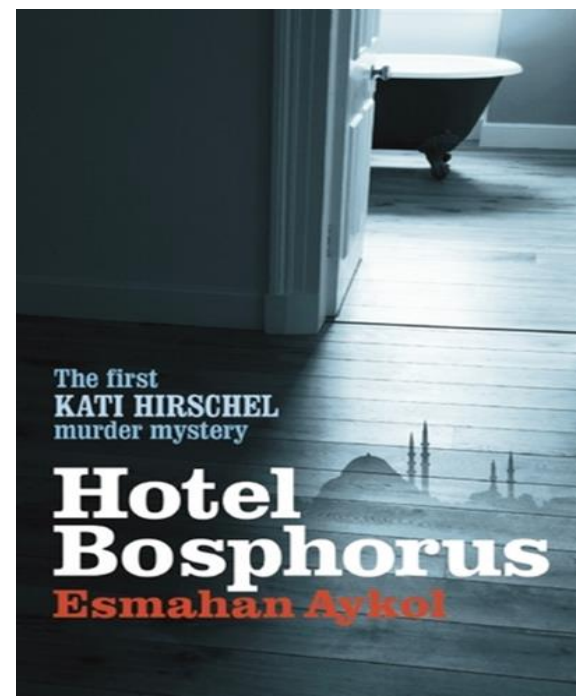


In Figure 1, the cover page of the first edition of the source text, published in 2001 by Everest Yayınları, is displayed. Figures 2 and 3 refer to the front covers of the other editions of the same source text published in 2007 by Merkez Kitaplar and in 2017 by Eksik Parça respectively, while Figure 4 displays the cover of the English translation published by Bitter Lemon Press.

Figure 1 contains a visual of the novel's heroine in Istanbul Istiklal Street with an image of the famous Taksim nostalgia tramway crossing the street in the background, whereas the main visual in Figure 2 is that of a bookshop in line with the original title of the novel, i.e., Kitapçı Dükkânı [The Bookshop] ${ }^{2}$. On the other hand, a white-colored bathtub is featured in Figure 3, clearly in connection with the fact that the victim of the novel was murdered in the bathtub in his room at the Hotel Bosphorus. In a similar vein with Figure 3, Figure 4, which belongs to the translated text, also includes a bathtub of which only half can be seen at the top of the page. It should be noted that, contrary to the bathtub in Figure 3 - which is one with a modern minimalist style, somewhat reminding of Scandinavian style - the bathtub in Figure 4 is a vintage one, which is a kind more likely to be found in an old hotel in Istanbul, such as the Hotel Bosphorus. However, what is striking about Figure 4 is not the bathtub, which is perhaps better suited for the context as compared to the one in Figure 3, but the silhouette of a mosque, more specifically the Süleymaniye Mosque, projected on the wooden floor of the hotel room situated at the bottom half of the cover page. As will be seen in the following sections, Hotel Bosphorus is, indeed, presented to target readership as a novel also including descriptions of Istanbul, but this does not change the fact that it is mainly composed to be a crime fiction. Yet, if it were not for the clear genre indication on Figure 4 marketing the novel as "The first KATI HIRSCHEL murder mystery", a potential reader by looking solely at the cover might have thought of it as a historical novel on the city of Istanbul.

The situation is not much different with regard to the front cover of the next Kati Hirschel murder mystery:

\footnotetext{
${ }^{2}$ All translations in square brackets, which are merely literal translations, are the authors'.
} 


\section{Figure 5}

The front cover of Kelepir Ev by Everest

Yayınları

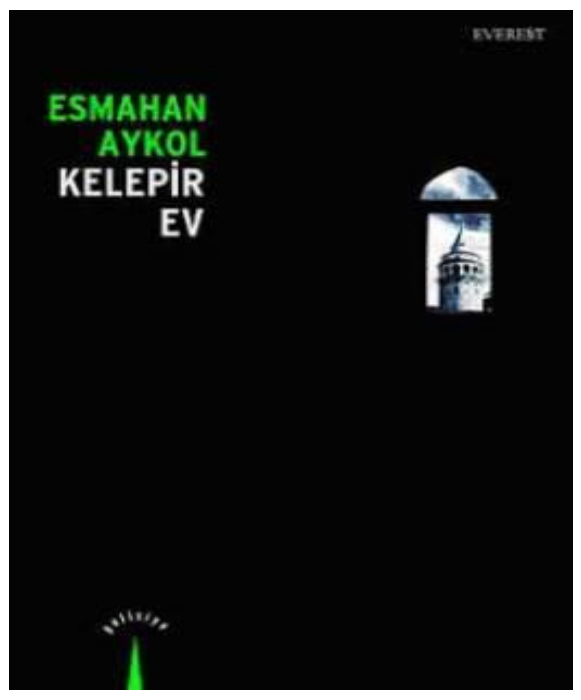

\section{Figure 6}

The front cover of Kelepir Ev by Merkez

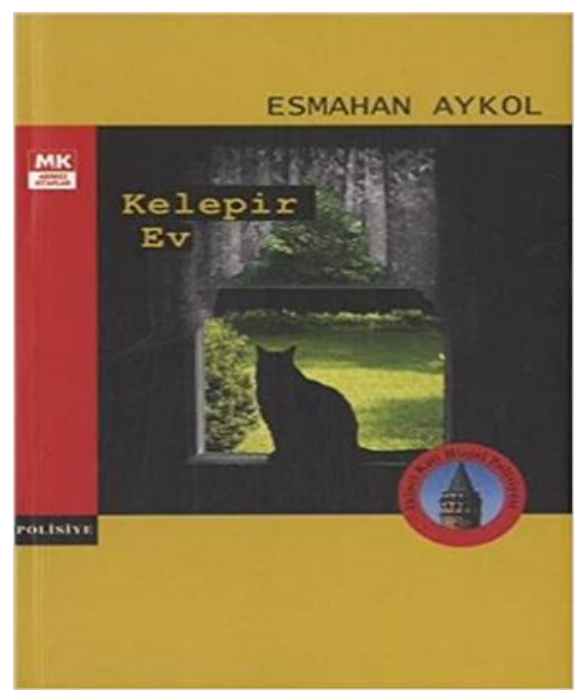

Figure 7

The front cover of Baksheesh by Bitter Lemon Press

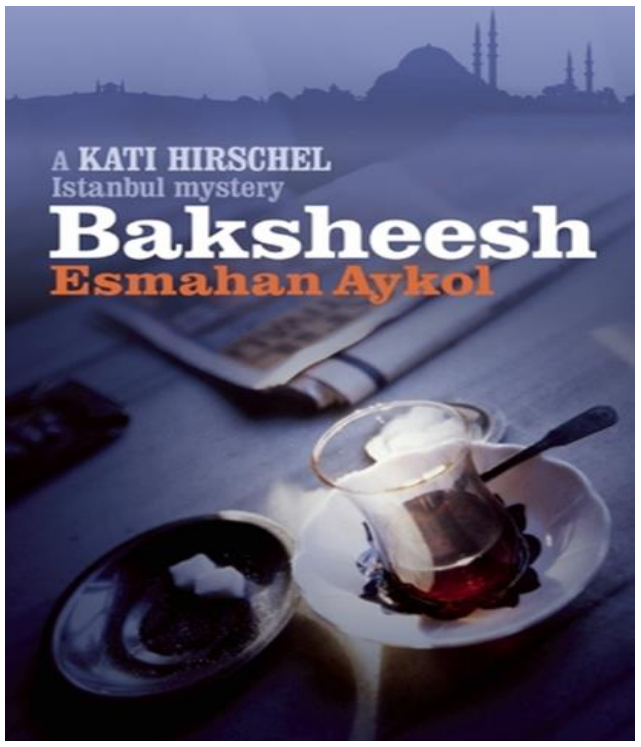


Kelepir Ev ${ }^{3}$ [Bargain Apartment] is the second novel of the series, first published in Turkey in 2003 by Everest Yayınları. The book was later translated into English with the title Baksheesh and released simultaneously in the UK and the USA in the year 2013. In this second novel, this time, our heroine Kati finds herself as the primary suspect of a crime when the dead body of a man is found in the apartment in Istanbul that she was trying to buy for a reasonable price by bribing a government officer. As can be deduced from Figure 5, which belongs to the source text published by Everest Yayınları, the novel is presented to Turkish readership with a rather modest cover page totally in black, bearing only a small window on the upper right corner through which part of the Galata Tower is seen. It can be said that this front cover is quite compatible with the plot, as the mysterious apartment where the murder takes place is situated at Kuledibi, the area in Istanbul where Galata Tower is. The other edition of Kelepir Ev by Merkez Kitaplar, as presented in Figure 6, is released in 2007 with a different front cover, featuring a black cat looking out of a window to a view of desolate green forest. It seems that this time, the creators of the cover aimed at giving the effect of misfortune and mystery with the use of the dark house, black cat, and desolate forest visuals. Contrary to this plainness and somberness of the source text covers, Baksheesh in English translation has quite a flashy as well as Eastern and more specifically Istanbulian looking cover. On the top of the cover is the Istanbul silhouette with the same mosque that we had seen before on the cover of Hotel Bosphorus. Under the Istanbul silhouette is a table on which there is tea served in a Turkish-style glass and next to the glass is its traditional companion, sugar cubes, again more commonly consumed in Turkish and Eastern cultures than the West. Finally, the two traditional elements on the table are complemented with a newspaper in front of them: a typical scene in a Turkish tea garden with a view of Istanbul. Just as in the case of Hotel Bosphorus, the mystery fiction attribute of the novel is announced to the potential reader with the statement on the cover, "A KATI HIRSCHEL Istanbul mystery", rather than the images used. Nevertheless, since the announcement "The first KATI HIRSCHEL murder mystery" [emphasis added] appearing on the front cover of Hotel Bosphorus is reformulated to read as "A KATI HIRSCHEL Istanbul Mystery" [emphasis added] in Baksheesh, it can be inferred that the producers of the paratext, for the second novel of the series, sought increased focus on the setting than on the genre. All in all, it can be said that while the front covers of the source text signal crime and mystery, the cover of the translated text is mostly evocative of the city of Istanbul.

When it comes to the last novel of the series analyzed within the framework of this study, one comes across an even more interesting choice of the publisher regarding cover illustrations of the translated text:

\footnotetext{
${ }^{3}$ There is one other cover format of the source text on the market by Everest Yayınları. Since it does not display significant deviations from the above-presented version, it has not been referred to in the present study.
} 
Figure 8

The front cover of Şüpheli Bir Ölüm by Merkez Kitaplar

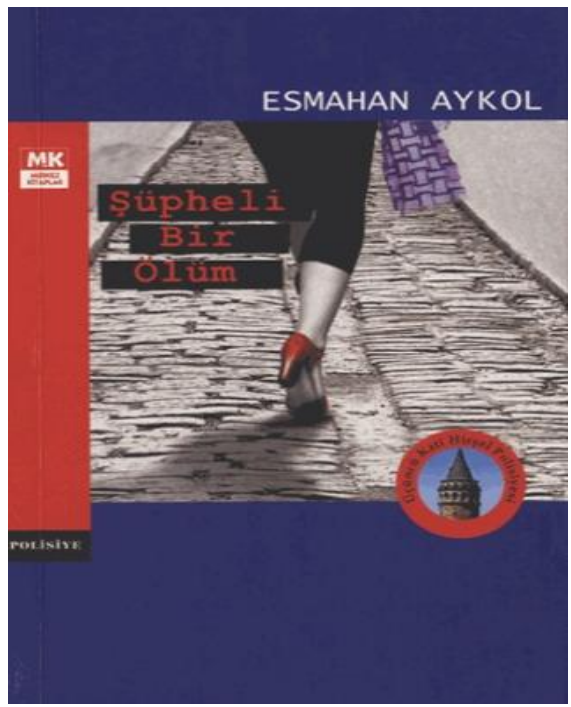

Figure 9

The front cover of Divorce Turkish

Style by Bitter Lemon Press

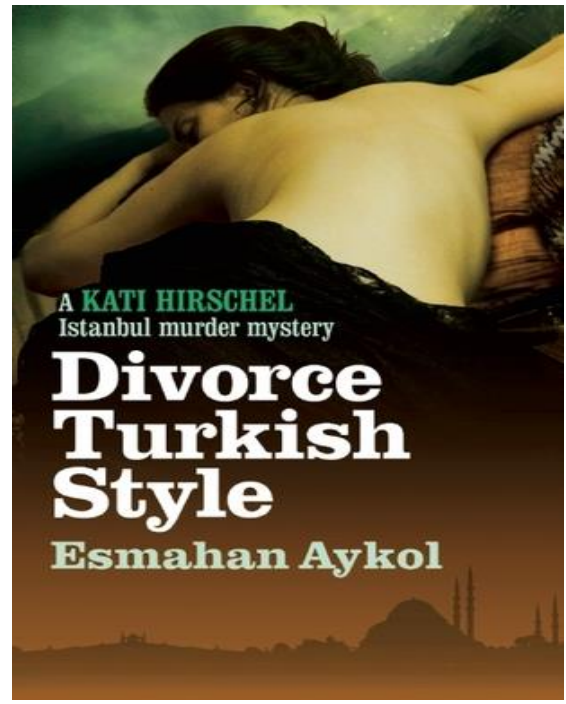

The novel was first published in 2007 in Turkey by Merkez Kitaplar with the title Şüpheli Bir Ölüm [A Suspicious Death] (Figure 8), while its translation in English was published in the year 2015 as Divorce Turkish Style (Figure 9). As can be predicted, in this third novel of the series, our amateur detective once more finds herself trying to solve a murder. In this case, the victim of the murder is an attractive young lady, Sani Ankaralıgil, who, as an active ecologist causing trouble to big companies, is also in the process of a divorce from her wealthy husband. On the cover of the source text shown in Figure 8, a well-dressed woman in a fashionable black slim skirt and red high heel shoes is walking down a cobblestone pavement street. The lady depicted on the cover is most probably the victim of the murder, and the fact that only the lower half of her body is seen gives the cover a mysterious effect in accordance with the genre. On the other hand, it can be observed that the novel in its English translation has been presented to the Anglo-American reader with totally different connotations as compared to the source version. The front cover of Divorce Turkish Style, as given in figure 9, features the same silhouette of Istanbul with the mosque, which was used for the covers of the other two novels, at the bottom of the cover page. On the upper part of the cover is a figure of a half-nude woman who seems to be sleeping face down. It is intriguing that the image utilized here, which covers the upper half of the page, reminds of the imaginative paintings on women in the Ottoman harem as produced by Orientalist artists. Considering that none of the women characters of the novel can in any way be identified with this image, it will not be misleading to assert that the producers of the 
book cover preferred to offer to the target reader a rather Orientalist looking cover than a thematic one.

The above-given front covers thus reveal that using the image of mosque, together with other visuals evocative of the East or Turkey, is a strategy systematically adopted by the publisher Bitter Lemon Press in introducing the English translations of Esmahan Aykol's Kati Hirschel series in the Anglo-American literary system. Moreover, a glance at some other Turkish novels of the same genre available in English translation reveals that the use of the mosque visual, as perhaps the most stereotypical image related to Istanbul in the eyes of the West, is very common for the presentation of Turkish crime or detective fiction to the Anglophone world. Selçuk Altun's detective novel published in England with the title Songs My Mother Never Taught Me (2008) features a mosque visual on its cover, whereas, in great contrast to the cover of the translated text, the front cover of the source text contains a sculpture of a man with wings, an image rather reminiscent of the ancient Rome than Istanbul. All four of the Hop-Ciki-Yaya thriller series from Mehmet Murat Somer, namely, The Kiss Murder (2008a), The Prophet Murders (2008b), The Gigolo Murder ${ }^{5}$ (2009), and The Serenity Murders / The Wig Murders (2012) contain a mosque visual on their covers ${ }^{6}$. Perhaps even more noteworthy is that this tendency of publishers does not only relate to crime fiction from Turkey translated into English. A good number of the detective Cetin Ikmen Istanbul mystery series by the crime fiction author Barbara Nadel feature, in varying sizes, an image of a mosque on their front covers ${ }^{7}$. In this instance, novels originally written in English were also introduced to their English readers with a mosque visual. This leads to the idea that, whether they be translations or not, it is perhaps quite common for publishers to opt for cover pages reminiscent of Istanbul in presenting murder mysteries - in which the main setting is Istanbul - to their Anglo-American readers. To put it differently, in the case of crime fiction taking place in the city of Istanbul, the creators of the book covers often give priority to emphasizing the setting as well as the foreignness of the novels rather than their genre, with regard to their choice of illustrations, perhaps to make them more tempting for the potential readers.

\footnotetext{
${ }^{4}$ This remark refers to the Penguin Group edition published in the USA, while the Serpent's Tail edition released in the UK does not contain a mosque on its cover.

${ }^{5}$ This remark refers to the Serpent's Tail edition published in the UK, while the Penguin Group edition released in the USA does not contain a mosque on its cover.

${ }^{6}$ However, this remark is to be interpreted neither as all Turkish novels in the genre crime fiction are presented to the Anglo-American world with a mosque image on their covers, nor as this tendency of publishers is limited to the genre in question. Contrary to the above-given cases, for instance, another thriller from Selçuk Altun, Many and Many a Year Ago (2009) features a visual of what seems to be a church on its cover, while its Turkish version has a mosque image on the background of the cover page. Some other examples of murder mysteries from Turkey in English translation whose covers were not decorated with a mosque visual are The Messenger Boy Murders (2003) by Perihan Mağden and The Murders at Castletop (2011) by Cüneyt Ülsever. Furthermore, a glance at the cover pages of novels from Turkish authors available in English translation reveals that the use of the mosque image, or another visual evocative of the city of Istanbul or Turkish culture, is a strategy occasionally utilized by publishers in presenting Turkish literature in other genres as well.

7 https://www.fictiondb.com/series/inspector-ikmen-barbara-nadel 19654.htm [retrieved September 24, 2021]
} 


\subsection{Book Titles}

Without doubt, the title of a work of literature, together with its cover illustrations, plays a crucial role in its presentation and dissemination in the target context. Genette highlights this significance of the title with the following remarks:

If the addressee of the text is indeed the reader, the addressee of the title is the public .... The title is directed at many more people than the text, people who by one route or another receive it and transmit it and thereby have a hand in circulating it. For if the text is an object to be read, the title ... is an object to be circulated - or, if you prefer, a subject of conversation. (1997, p. 75)

As these statements make clear, while the literary text reaches only those who obtain and read it, the title has a much broader audience, that is to say, the public in general. As an "object to be circulated", and as one of the most immediately visible paratexts a potential reader comes across, it can safely be assumed that the choice of title in translation may give us important clues on the way a book is intended to be presented to the target readership.

Just as the case with the cover page illustrations, all three of the titles of Esmahan Aykol novels analyzed in this study have been subject to some conspicuous changes during their translational adventure. The first of the Kati Hirschel murder mystery series entitled Kitapçı Dükkânı [The Bookshop] in its Turkish version was introduced to the Anglo-American world in translation with the title Hotel Bosphorus. In the case of the second novel of the series, the original title Kelepir Ev [Bargain Apartment] was transformed in its English translation to read as Baksheesh, a word of Persian origin that has different connotations in Turkish and English languages. In the dictionary of the Turkish Language Association, bahşiş [baksheesh] is defined as "extra money given apart from the price paid for a service rendered, coffee money" ${ }^{89}$, whereas in the English context the word in question means "A gratuity, tip, or bribe paid to expedite service, especially in the Near East." ${ }^{10}$ As is evident from the given definitions, while the word has rather positive connotations in the Turkish culture, in English, it also has some negative connotations with its bribe meaning. Obviously, the producers of the English title wanted to arouse this negative connotation in potential readers' minds when selecting this title, in line with the novel's plot where the heroine bribes an official to buy an apartment at a bargain price. As regards the third novel of the Kati Hirschel series, the Turkish title Şüpheli Bir Ölüm [A Suspicious Death] was rendered into English as Divorce Turkish Style. All three of these translation practices are remarkable since, in all cases, the titles of the target texts have no semantic similarity with those of the source texts. Moreover, although undoubtedly the titles preferred for the translated novels are also, more or less, coherent with the plots, it can be observed that - besides the semantic shifts - the titles have undergone significant shifts in the process of translation concerning their foci as compared to their source versions. To be more precise, while a

\footnotetext{
${ }^{8}$ Authors' translation.

${ }^{9}$ https://sozluk.gov.tr/ [Yapılan bir hizmete ödenen ücretten ayrı olarak fazladan verilen para, kahve parası] [retrieved June 13, 2021]

${ }^{10} \mathrm{https}: / /$ www.thefreedictionary.com/baksheesh [retrieved June 13, 2021] 
bookshop or a bargain apartment for sale can be found and a suspicious death can exist in any culture or country in the world, this universality of the source text titles is replaced by a focus on locality or otherness in the translated titles. In this respect, the title Hotel Bosphorus clearly reminds of the city of Istanbul whereas Baksheesh and Divorce Turkish Style are evocative, at first sight, of the East and Turkey respectively. Besides, it can be alleged that the last two titles also point to Istanbul when interpreted together with the other paratextual elements on the book covers, i.e., Istanbul silhouettes featuring mosque visuals and the written announcement that the novel is an "Istanbul mystery". Aykol also confirms this emphasis on Istanbul in the titles of her translated novels with the following remarks:

My German publisher Diogenes prefers titles which readers can associate with Istanbul as soon as they see the books on the shelf. I think this approach is right because in the end I write crime novels about Istanbul. For the other languages that followed the German translations, publishers used the titles in German because they also preferred to give their readers a message about Istanbul. (as cited in Eker Roditakis, 2014, p. 47)

These statements make explicit that, as the decision-making authority regarding title selection for Esmahan Aykol novels in German translation, the publisher Diogenes Verlag AG has particularly opted for book titles related to Istanbul, obviously as a marketing strategy. What is perhaps even more remarkable concerning these statements is Aykol's reference to the fact that, in presenting the translations of her novels in other languages, publishers from those countries have also preferred to use the titles created by Diogenes, rather than the source text titles in Turkish. In fact, as also exemplified by Eker Roditakis (2014, p. 46) for the case of Kitapçı Dükkânı, when the translated titles of the three novels under analysis in other languages are examined, it is seen that many publishing houses from all around the world have opted for the same or similar titles with those of the German versions. Kitapçı Dükkânı, which, as stated before, was published in the English language in 2011 with the title Hotel Bosphorous, was also translated to Greek and Hungarian in 2005, Spanish in 2007, Italian in 2010, Croatian in 2014, Romanian in 2015 and Bulgarian in 2016, with the literal translation of its German version's title released in 2003, i.e., Hotel Bosporus. Furthermore, the book was released in French in 2006, Serbian in 2009, and Macedonian in 2014 with a very similar title, which can be rendered in English as Murder at the Bosphorus Hotel and in Arabic in 2017 as Crime in the Bosphorus. Similarly, Aykol's second novel Kelepir Ev, again first published in German (after its Turkish version) by Diogenes in 2004 as Bakschisch, and in English in 2013 as Baksheesh, was also translated to French in 2011 with a title whose literal translation corresponds to Baksheesh. On the other hand, although it was observed that publishers of the same novel in Italian and Arabic have challenged this general trend of adopting the titles of Diogenes, we once again come across interesting decisions regarding title selection. In these cases, Kelepir Ev was rendered in Italian in 2011 with the title Apartment in Istanbul and Arabic in 2018 as Crime in Istanbul, thus, this time, the message about Istanbul was given to potential readers directly by inserting the name of the city to the title when it does not exist in the Turkish version. Finally, Aykol's last novel in the series available in English 
translation, Şüpheli Bir Ölüm, translated into English in 2015 as Divorce Turkish Style, was introduced to readers in German in 2008, Italian in 2012, and Arabic in 2020, all with titles which can literally be translated as Divorce Turkish Style. ${ }^{11} 12$

This tendency of publishers from around the world to opt for the titles of Diogenes instead of the titles in Turkish may well be associated with the popularity of Istanbul as a center of attraction with its rich history. It may also be argued that exotic titles like Baksheesh and Divorce Turkish Style must have been deemed as more attractive marketing devices for publishers, assuming that their potential readers would expect to also learn about another culture by purchasing a piece of international literature. Eker Roditakis (2014) brings a reasonable perspective to this international journey of translated titles between literary systems, stating that:

this phenomenon is more to do with the dynamics of how Turkish literature in translation travels through Europe, and of the interaction between the publishing sectors in each target system, brought about by actors such as translators, literary agents and publishers who come into contact through professional networks or at book fairs throughout Europe. (p. 46)

This remark can be furthered by suggesting that this interaction has now extended the borders of Europe to cover non-European countries as well, as revealed by the above-given cases of titles in Arabic.

All in all, with their references to the city of Istanbul, Turkey, and the East, just like the cover illustrations, the book titles of Aykol's novels in English have undergone significant shifts in the process of translation, in confirmation with Richard Watts' (2005) remark that "the paratext is not translated per se but reimagined or completely transformed" (p. 161). The focus on these titles, first created for the German translations of the novels and later adopted by many other publishers from around the world, including Bitter Lemon Press, has been more on locality and foreignness than on the crime fiction attribute of the works in question, presumably to cater to the anticipated expectations of the target audience. If -unlike Aykol's view that the title of a book is not that important for a reader (as cited in Eker Roditakis, 2014, p. 47) - as Umberto Eco puts forth "A title, unfortunately, is in itself a key to interpretation" (1984, vi), then, by opting for such titles, the producers in the target system have aimed at completely different interpretations than their corresponding agents in the source system.

At this point, it is deemed necessary to turn to Edward W. Said's theory of Orientalism to better interpret this kind of representation of Turkish literature in translation. One of the definitions of Orientalism as put forth by Said (1979) is "a style of thought based upon an ontological and epistemological distinction made between

\footnotetext{
11 The literal translations for titles in languages other than Turkish and English are obtained by means of machine translation.

12 It should be noted that, here, we may have failed to cover all languages that the novels under analysis are available in, as, providing a comprehensive list of all the translations of the Kati Hirschel series falls out of the scope of this article. Information on the mentioned translated novels is obtained from several websites introducing/marketing works of literature, mainly Amazon.com and Goodreads.com.
} 
'the Orient' and (most of the time) 'the Occident'" (p. 2). He states that the work of many writers focusing on the Orient within different fields, including literature, are grounded on this distinction (pp. 2-3). Moreover, in its other meaning, Orientalism refers to "the corporate institution for dealing with the Orient - dealing with it by making statements about it, authorizing views of it, describing it, by teaching it, settling it, ruling over it" (p. 3). Said argues that it was by locating and describing the Orient as its opposite image that the West had been able to define itself and, in a way, construct its identity (pp. 12). In this sharp distinction generated between the two poles, the Occident is "rational, developed, humane, superior", while the Orient is "aberrant, undeveloped, inferior" (p. 300). Furthermore, in the Orientalist way of thinking, even now, the Orient is defined based on assumed abstractions about the classical Oriental civilizations rather than the realities of the modern Oriental world (p. 300), i.e., the Orient is confined to the once created image attributed to it by the West, in total ignorance of its unsteadiness. Consequently, the idea that "the Orient is eternal, uniform, and incapable of defining itself" legitimizes the West's generalized discourses concerning the whole of the Orient (p. 301). From the peritextual analysis of front covers, it is evident that Aykol's novels, in being introduced to the Anglophone culture with visuals of mosque and harem woman along with exotic titles, could not escape being subject to Oriental generalizations as pieces of literature belonging to the Orient, in contrast to their source text versions which are not distinctly Oriental at all. These detective novels that are part of contemporary Turkish literature and take place in modern Turkey are peritextually archaized, exoticized, uniformized, and generalized to fit into the West's prevailing perceptions and representations of the other, thus, Orientalized.

\subsection{The Translator's Name}

The existence or nonexistence of the translator's name on the front cover is significant in that it gives clues regarding the power relations in translation activity, the former case increasing the translator's power as an agent (Kansu-Yetkiner et. al., 2018, p. 19). As can be observed from the above-given figures, unlike the name of the author that is written on the front covers of the target texts in attention-grabbing colors and remarkable font sizes, the name of the translator does not appear on any of the analyzed covers. Although the translator's name is given on the inner pages of all the translated texts, this preference of the publisher to exclude the translator from the most immediately visible part of the novels is affirmative of Lawrence Venuti's (1995) assertion on the prevailing invisibility of the translator in the contemporary Anglo-American world, at least for the case of Aykol's novels in English translation. Borrowing the terms from Friedrich Schleiermacher, Venuti (1995) states that a translator may either adopt a domesticating strategy by "bringing the author back home" or a foreignizing strategy by foregrounding the differences of the source language and culture and thus "sending the reader abroad" (p. 20). Applying these terms to the peritextual choices regarding the front covers under analysis, it can be said that foreignizing strategy is adopted concerning the visuals and titles of the target texts, given that their otherness is systematically highlighted to the extent that the universal appeal of their corresponding peritexts in the source texts is lost in translation. However, despite all the foreignness 
manifested on the target text covers, paradoxically, the invisibility of the translator leaves the covers with no direct indication that the books are translations. An analysis of the "Crime and Mystery Fiction"13 books published by Bitter Lemon Press displays that the preference of the publisher to exclude the translator's name from the front cover is not peculiar to Aykol's novels, as the translator is not mentioned in any of the translated fiction covers released under the series, while the foreignness of the novels is, in most cases, revealed by an indication of the country or city the book takes place in, if not apparent from the title. This indicates that, although the publisher's main activity involves publishing translations from around the world, the translator is not acknowledged or foregrounded as an active agent in the presentation strategies of the publisher.

\section{Analysis of the Back Covers}

The back cover of a book, which is another part embodying paratextual material of strategic importance, may include items of information such as the author's name, the book's title, biographical information on the author, the please-insert, information on previous publications of the author, blurbs or promotional statements, genre indication, date and number of re/printing, information on the cover's designer, price and ISBN (Genette, 1997, p. 26).

Undoubtedly, from among all these pieces of information, the most attentiongrabbing for a potential reader looking for a book to buy will be the book description and the promotional statements on the book, namely the blurbs. To begin with the first Aykol novel under analysis, Hotel Bosphorous (2011) is introduced to the AngloAmerican readership with its back cover as follows:

Katie Hirschel, is a foreigner and proud owner of the only crime bookshop in Istanbul. When the director of a film starring her old school friend is found murdered in his hotel room, Katie cannot resist the temptation to start her own maverick investigation. After all, her friend Petra is the police's principal suspect, and reading all those detective novels must have taught Katie something.

This suspenseful tale of murder features a heroine who is funny, feisty and undresses men in her mind more often than she would actually admit, even to herself. The men are too hot to handle, but is she too cool to resist? Sharp observation and wry, sexy humour expose Western prejudices about Turkey as well as Turkish stereotyping of Europeans.

As can be seen, the back cover first includes a brief book description followed by some information giving hints on the character traits of the novel's heroine. The fact that Kati is introduced as being funny and feisty suggests that the book offers the readers a story full of entertainment and possibly adventure. At first sight, the above description appears to be an ordinary one giving just the right amount of information on the book by still keeping the mystery alive, which is perhaps exactly what is expected of a murder mystery description, or, in fact, of any book description regardless of genre.

${ }^{13}$ https://www.bitterlemonpress.com/collections/crime-mystery-fiction-all-books [retrieved December 7, 2021] 
Nevertheless, two points related to this presentation deserve special consideration, particularly when it is compared with the back cover descriptions of the Turkish editions. The first of these is the incorporation of expressions to the description implying that the book also offers the readers some degree of erotism: "a heroine who ... undresses men in her mind", "The men are too hot to handle, but is she too cool to resist?" and "sexy humour". Considering that - although some feature statements signaling that, by obtaining the novel, the reader should also expect to read about Kati's relationship with men - none of the back cover descriptions of the Turkish editions are suggestive of erotism, it can be assumed that this is a strategy adopted by the creators of the peritext in the target system to render the translated book more appealing.

The second attention-grabbing occurrence in the above description is the statement that the book sheds light on "Western prejudices about Turkey as well as Turkish stereotyping of Europeans". Indeed, Aykol makes clear her discomfort concerning the West's stereotyping of Turkish culture and society on several platforms. In an interview with Çizmecioğlu (2008, para. 11), Aykol states that, while pursuing her PhD studies in Germany, her lecturers were surprised to hear that she was Turkish and, upon learning about her nationality, anticipated that she was from the non-Muslim minority because she did not wear a headscarf. She goes on to state that for her "writing is a chance to do away with this type of lazy cliché" (Çizmecioğlu, 2008, para. 12). In another interview entitled Challenging Stereotypes (2011), the writer expresses her inconvenience in constantly being exposed to prejudiced questions on Turkish lifestyle or even derogatory questions like whether she knew Mozart, again when studying in Germany. She then adds that it was this prejudiced stance on Turkish society that led her to display with her debut novel Hotel Bosphorus, that there are "'different' Turks, far from the stereotyped images" (Cornwell, 2011, para. 1). Although textual analysis has not been conducted within this research, one can well infer from the above statements that this negative stance of the author towards stereotyping is also reflected in her novels. Considering all this information, it is however quite surprising that all three of Aykol's novels analyzed in this paper have been presented to the target readership with cover page illustrations and titles that rather reinforce stereotypes, let alone challenge them. That is to say, the author's epitexts, i.e., Aykol's statements in interviews, are mostly in contrast with the publisher's peritexts, i.e., the front cover visuals and titles. This leads one to think that, as was the case with titles, the writer totally left the selection of the cover page illustrations to the translational agents of the target system. It seems that the paratextual decisions of these agents can be explained with Brian Mossop's statement that while covers "may certainly convey aspects of the text, or at least not contradict it, the meaning of the text may also be sidelined, suppressed or even negated by another, much more important function of covers: they are first and foremost marketing devices" $(2018$, p. 2). Taking into account the potential power of the peritextual material in question on the reception of the translated texts, it can be said that the actors of the receiving literary system authorized for the marketing mission have determined different destinies for the novels by creating different images 
for them as compared to what Aykol wanted to create, to which the author did not object.

The back cover also includes the following endorsements on the novel:

A wonderful novel about Istanbul. The Turkish way of life, prejudices, men, politics, corruption-Esmahan Aykol writes about all these with a light and humorous touch. Petros Markaris, author of Che Committed Suicide and Zone Defence

Bubbling with hedonism, enthusiasm, love of life and books, this should be mandatory reading for those holidaying in Turkey, visitors to Istanbul, and lovers of crime novels. Hamburger Abendblatt

The first blurb is penned by Petros Markaris, a Greek-Armenian writer of murder mysteries who was born in Istanbul, while the second one is by a long-established daily newspaper operating in Hamburg. By selecting these blurbs to appear on the back cover, it seems that the publisher has sought to increase the attractiveness and the credibility of the work of a foreign writer, who has newly entered into the target literary system, with the help of praises. In the former case, this goal is intended to be achieved with the use of an endorsement by another author producing in the same genre whose books were already available in English translation before Aykol made her debut, that is to say, a writer more familiar for the target readership. On the other hand, the praise by a German newspaper in the latter case may be there to allude that the book has already been translated into and well-received in another European language and culture, i.e., that it is a novel worth reading. What is even more notable about the above blurbs is not who wrote them but what information they give. Interestingly, both praises about the book underscore its feature as a novel about Istanbul rather than its being a murder mystery. While the first blurb solely points to the fact that the book gives information on various aspects of Istanbul, Turkish culture and lifestyle, the second one mentions that it should be of interest to readers of crime novels only after emphasizing that it is a must to read "for those holidaying in Turkey, visitors to Istanbul". Thus, once more, we come across a paratextual decision where the novel's relatedness with Turkey and Istanbul is foregrounded rather than its genre or any other feature. With the use of these blurbs on the back cover, Hotel Bosphorus is marketed not only as a piece of literature from abroad, but also as a book that takes one on a journey abroad, to a city of historical importance for many civilizations, which will arguably make it appear more attractive for those interested in foreign cultures, and more specifically in Istanbul. Moreover, it can be said that this strategy of the publisher appears to be in harmony with the expectations of the target audience since, when asked about the reactions she received on Hotel Bosphorus, Aykol expresses that many readers like the fact that her novels also function as a city guide and that people who have read her books mention their desire to visit Istanbul (Cornwell, 2011, para. 19).

This focus on Turkey and Istanbul is also pursued on the back cover of the second Kati Hirschel mystery, Baksheesh (2013). This time, the book description starts with a similar statement to which was present on the front cover, the announcement that Baksheesh is "The second Kati Hirschel Istanbul mystery". This is followed by two short 
paragraphs containing brief information on the plot and a third paragraph, which reads as follows:

In her second novel Esmahan Aykol takes us to the alleys and boulevards of cosmopolitan Istanbul, to luxurious villas and seedy basement flats, to the property agents and lawyers, to Islamist leaders and city officials - in fact everywhere that baksheesh helps move things along.

With this statement, the reader is once more informed that the novel offers insight into the city of Istanbul as well as different sections of Turkish society. The expectation created by using this sentence is further strengthened with two praises for Hotel Bosphorus. The first one of these is the above-mentioned endorsement by Markaris that had been used on the back cover of Hotel Bosphorus. The second praise for the first novel in the series is from Crime Time:

As a portrait of a fascinating city Hotel Bosphorus paints an intriguing and humorous picture. I look forward to more tales of strong Turkish coffee and cigarettes.

Just like the comment of Markaris, the novel is again introduced with its depictions of Istanbul on focus. Thus, when the back covers of Hotel Bosphorus and Baksheesh are considered together, it can be said that, for the first two Kati Hirschel murder mysteries, the fact that they provide a considerable amount of depictions related to Istanbul and Turkish lifestyle is the feature of the novels primarily foregrounded in the blurbs.

As regards the last novel subject to analysis, Divorce Turkish Style (2015), the city is on the scene afresh as the central theme in one of the three praises for Aykol appearing on the back cover:

Istanbul's sights, sounds, and timeless customs are woven so deeply into the narrative that the story couldn't take place anywhere else. Aykol is adept not only at creating fascinating characters, but also at bringing a city to life. - Suspense Magazine

With this praise, the significance of Istanbul in the creation of Divorce Turkish Style is unquestionably made evident as the city is defined to be an indispensable and inseparable feature of the book to the extent that "the story couldn't take place anywhere else". On the other hand, it is observed that other features of the novel and/or the writer could also find room for themselves in the blurbs of the third Kati Hirschel mystery available in English translation:

In Aykol's impressive Kati Hirschel mystery set in Istanbul, Kati once again turns amateur sleuth with aplomb. - Publishers Weekly

Aykol plots cleverly, works in knowing comments on the clichés of the crime genre, and she does a nice line in wittily undermining national stereotypes. - New Internationalist

Unlike all the other above-mentioned blurbs, the prominent aspects in these praises are the genre as well as Aykol's mastery in handling the genre and in developing the plot. Taken together with Suspense Magazine's comment about the author's success "at creating fascinating characters", it can safely be asserted that the emphasis on 
Istanbul and Turkish lifestyle encountered on the back cover statements of the first two novels has been shifted to other literary features in the case of Divorce Turkish Style, if not totally abandoned. However, the local essence is still kept on the back cover with the book description mentioning that one of the suspects may be the murdered woman's "jealous husband seeking revenge through an honor killing". By the insertion of honor killing, a fact often associated with patriarchal societies, expectedly when it does not exist in the book description of the Turkish version, the creator of the peritext has once again turned to stereotypes, again in incongruity with the above comment of New Internationalist that Aykol "does a nice line in wittily undermining national stereotypes".

Considered altogether, the peritextual material included on the translated back covers also bear certain references to the Orientalist way of thinking. The idea of the undevelopedness and inferiority of the Orient as compared to the developed and superior West as constituting one of the fundamentals of Orientalism had been mentioned before. Said (1979) states that, based on this idea, in the Western film sector, the Oriental Arab has always been depicted with negative traits as being dishonest, trickster, inferior and lecherous, and has appeared in traditional roles such as "slave trader, camel driver, moneychanger, colorful scoundrel" (pp. 286-287). In a similar vein, it is observed that in the information provided on the analyzed back covers of the translated texts, the Turkish society is associated with corruption, prevailing bribery in every segment of the public and private sphere, and honor killings. Since analysis at the textual level has not been conducted within the present study, it would not be possible to suggest that these kind of representations through peritexts are exaggerated or incompatible with the texts they represent, given that these negative attributions may well be handled in the novels as well. In fact, in some of the source text book descriptions, it is mentioned that Aykol directs criticisms towards Turkish society in the novel. Nevertheless, from an analysis of the translated texts' back covers in comparison with those of the source versions, it can be said that, in general, the agents in the target system involved in composing the peritextual material have embraced a much more marked Orientalist discourse in the presentation of the novels to Anglo-American readers.

To sum up, if the paratext is "the text that surrounds and supports the core text, like layers of packaging that initially protect and gradually reveal the essence of the packaged item" (Pellatt, 2013, p. 1), then, the essence as revealed with the paratextual material of the English translations is remarkably different from that of the source texts.

\section{Conclusion}

The present paper, which has set out to explore the reception and presentation of Esmahan Aykol's novels in English translation as reflected in peritextual material contained on book covers, can be taken as a modest attempt to contribute to the increasing utilization of paratextual analysis to explain the complex phenomena of translation. Within this framework, the front and back covers of three Kati Hirschel murder mysteries by the author, namely, Hotel Bosphorus, Baksheesh, and Divorce 
Turkish Style, published in the UK and the USA, have been analyzed comparatively with their respective source text material. The results of the analysis reveal several elements or themes repeatedly foregrounded in the introduction of Aykol's novels to the AngloAmerican readership.

To start with the illustrations used on the front covers of the translated texts, it has been observed that all three covers are decorated with one of the most iconic sites directly identified with the city of Istanbul, i.e., a mosque image. In the case of the second and third novels of the Kati Hirschel series, the foreignness of the novels as manifested in the use of the mosque image is further brought to the fore with other culture-bound or stereotypical visuals like traditional Turkish tea glass accompanied by sugar cubes and a painting of an imaginative woman from the Ottoman harem. In a similar vein with the illustrations, the book titles have also undergone significant changes in the translation process, by being transformed into titles evocative of Istanbul, Turkey, and/or the East. In this process of transformation, the universal appeal of the source titles has left itself to locality, foreignness, and exoticism, especially when considered together with the front cover illustrations. On the other hand, in all front covers, the genre indication for the novels is enabled with statements presenting them as, "The first KATI HIRSCHEL murder mystery", "A KATI HIRSCHEL Istanbul mystery" and "A KATI HIRSCHEL Istanbul murder mystery" respectively, rather than the visuals or titles. Thus, the findings of the front cover analysis display that, in the case of Aykol's novels, the peritexts are completely recreated, given that the covers of the novels in English translation have no resemblance whatsoever with those of their source text versions.

As regards the presence of the translator on the front covers, the analysis has demonstrated that, despite and in contrast to the foreignizing strategy adopted in the selection of illustrations and titles for the translated novels, the translator's name does not appear on any of the covers. This invisibility of the translator is indicative of the passive role attributed to her in the presentation of Aykol's novels to Anglo-American readers. To put it differently, as, in fact, one of the most crucial actors in the books' entrance into the target literary system, paradoxically, the translator was not acknowledged as an active agent in the reception and presentation policies of the publisher.

It has been observed that the deviation of front covers from the peritextual material contained in the source texts, in favor of more focus on Istanbul and Turkey, is also pursued on the back covers of the translations in varying degrees. In this sense, the analysis has displayed that, in many cases, the main focus of the book descriptions and blurbs featured in the translated texts has been on the books' connectedness with the city of Istanbul, life in Istanbul as well as with Turkish culture and lifestyle, as opposed to their source text correspondents that predominantly mention the plot, genre, style, and literary merit. Furthermore, it has been seen that, in some cases, this focus exists side by side with other efforts to render the books more appealing for potential readers 
by, for instance, inserting to descriptions statements pointing to erotism or honor killings.

As stated before, the fact that the cover is primarily a marketing device may result in its sacrificing the meaning of its text for the sake of successfully fulfilling this marketing function. For the case of Aykol's novels in English translation, it would not be apt to say that the emphasis given to Istanbul in the peritextual material contradicts the literary texts since, as mentioned above, eventually, the author writes murder mysteries on Istanbul. However, it can perhaps be said that the use of stereotypical images on covers such as mosque and harem woman, or statements like honor killing has resulted in the sidelining of a significant feature of the texts as revealed by the paratextual material examined in the previous parts, i.e., the negative stance towards cultural stereotyping present in them. Moreover, it can be asserted that the genre and universality of the novels, which are mostly addressed in the source texts' peritexts, have also been sidelined in the target texts' peritexts for the benefit of foregrounding the setting and locality. This localization, foreignization, and exoticization of peritextual material in translation, through which, in many instances, stereotypes and clichés attributed to the Orient by the Occident are pursued, has also displayed that the Orientalist style of thought has been influential in the presentation strategies of the creators of the peritexts. All in all, with all these shifts in translation, the peritexts of the source and target texts evoke remarkably different connotations and essences regarding the texts to which they belong.

\section{References}

Aktener, I. (2019). A case study of translator's preface in Yok Edici. RumeliDE Dil ve Edebiyat Araştırmaları Dergisi, (14), 439-453. https://doi.org/10.29000/rumelide.541081

Altun, S. (2008). Songs my mother never taught me (R. Christie \& S. Berilgen, Trans.). Telegram Books.

Altun, S. (2009). Many and many a year ago (C. Endres \& S. Endres, Trans.). Telegram Books.

Aykol, E. (2001). Kitapçı dükkânı. Everest Yayınları.

Aykol, E. (2003). Kelepir ev. Everest Yayınları.

Aykol, E. (2007a). Kelepir ev. Merkez Kitaplar.

Aykol, E. (2007b). Kitapçı dükkânı. Merkez Kitaplar.

Aykol, E. (2007c). Şüpheli bir ölüm. Merkez Kitaplar.

Aykol, E. (2011). Hotel Bosphorus (R. Whitehouse, Trans.). Bitter Lemon Press.

Aykol, E. (2013). Baksheesh (R. Whitehouse, Trans.). Bitter Lemon Press.

Aykol, E. (2015). Divorce Turkish style (R. Whitehouse, Trans.). Bitter Lemon Press.

Aykol, E. (2017). Kitapçı dükkânı. Eksik Parça.

Batchelor, K. (2018). Translation and paratexts. Routledge. https://doi.org/10.4324/9781351110112 
Canlı, G., \& Karadağ, A. B. (2019). William Faulkner'ın Sanctuary romanının Türkçede nasıl adlandırıldığı üzerine betimleyici bir çalışma. RumeliDE Dil ve Edebiyat Araştırmaları Dergisi, (14), 454-468. https://doi.org/10.29000/rumelide.541084

Cornwell, B. (2011, May 10). Challenging stereotypes - Esmahan Aykol talks to Bob Cornwell. Crime Time. https://www.crimetime.co.uk/Challenging-Stereotypes-Esmahan-AykolTalks-To-Bob-Cornwell/

Çizmecioğlu, A. (2008, January 14). Esmahan Aykol: "Goodbye Istanbul" - Between fiction and reality. Qantara.de. https://en.qantara.de/content/esmahan-aykol-goodbye-istanbulbetween-fiction-and-reality

Demirkol Ertürk, Ş. (2019). Retranslating and repackaging a literary masterpiece from a peripheral language: The functions of paratexts in recontextualizing literary translations. In Ö. Berk Albachten \& Ş. Tahir Gürçağlar (Eds.), Studies from a retranslation culture: The Turkish context (pp. 137-154). Springer. https://doi.org/10.1007/978-981-13-7314-5 9

Eco, U. (1984). Postscript to the name of the rose. Harcourt Brace Jovanovich.

Eker Roditakis, A. (2014). A paratextual look at the Greek translations of Turkish novels. Istanbul $\begin{array}{llll}\text { Üniversitesi Çeviribilim } \quad \text { Dergisi, 39), } & \text { 398. }\end{array}$ https://dergipark.org.tr/tr/pub/iuceviri/issue/1233/14479

Farlex. (n.d.). Baksheesh. In The free dictionary. Retrieved June 13, 2021, from https://www.thefreedictionary.com/baksheesh

Genette, G. (1997). Paratexts: Thresholds of interpretation (J. E. Lewin, Trans.). Cambridge University Press. https://doi.org/10.1017/CBO9780511549373

Hermans, T. (1996). The translator's voice in translated narrative. Target: International Journal of Translation Studies, 8(1), 23-48. https://doi.org/10.1075/target.8.1.03her

Kansu-Yetkiner, N. (2014). Words apart, worlds apart: Peritexts from Islamized translations of world classics in children's literature. Children's Literature in Education: An International Quarterly, 45(4), 340-353. http://dx.doi.org/10.1007/s10583-014-9218-y

Kansu-Yetkiner, N., Duman, D., \& Avşaroğlu, M. (2018). Çevirmen neredesin? Çocuk edebiyatı yanmetinlerinde çevirmenin kılıcı rolü ve görünürlüğüne artsüremli bir yaklaşım: 19292013. Çeviribilim ve Uygulamaları Dergisi, (24), 17-34.

Kovala, U. (1996). Translations, paratextual mediation, and ideological closure. Target: $\begin{array}{llll}\text { International Journal of Translation } & \text { Studies, 8(1), } 147 .\end{array}$ https://doi.org/10.1075/target.8.1.07kov

Lefevere, A. (1992). Translation, rewriting, and the manipulation of literary fame. Routledge.

Mağden, P. (2003). The messenger boy murders (R. Hamer, Trans.). Milet Publishing.

Mossop, B. (2018). Judging a translation by its cover. The Translator, 24(1), 1-16. https://doi.org/10.1080/13556509.2017.1287545

Oktar, L., \& Kansu-Yetkiner, N. (2012). Different times, different themes in Lady Chatterley's Lover: A diachronic critical discourse analysis of translator's prefaces. Neohelicon, Acta Comparationis Litterarum Universarum, 39(2), 337-364. https://doi.org/10.1007/s11059$\underline{012-0142-0}$ 
Pellatt, V. (2013). Introduction. In V. Pellatt (Ed.), Text, extratext, metatext and paratext in translation (pp. 1-6). Cambridge Scholars Publishing.

Said, E. W. (1979). Orientalism. Vintage Books.

Somer, M. M. (2008a). The kiss murder (K. Dakan, Trans.). Penguin Books.

Somer, M. M. (2008b). The prophet murders (K. Dakan, Trans.). Serpent's Tail.

Somer, M. M. (2009). The gigolo murder (K. Dakan, Trans.). Serpent's Tail.

Somer, M. M. (2012a). The serenity murders (A. M. Spangler \& I. Aydoğan, Trans.). Penguin Books.

Somer, M. M. (2012b). The wig murders (A. M. Spangler \& I. Aydoğan, Trans.). Serpent's Tail.

Tahir-Gürçağlar, Ş. (2002). What texts don't tell: The uses of paratexts in translation research. In T. Hermans (Ed.), Crosscultural transgressions. Research models in translation studies II: Historical and ideological issues (pp. 44-60). St Jerome Publishing.

Tahir-Gürçağlar, Ş. (2011). Paratexts. In Y. Gambier \& L. van Doorslaer (Eds.), Handbook of translation studies volume 2 (pp. 113-16). John Benjamins. https://doi.org/10.1075/hts.2.par1

Tekgül, D. (2011). Marketing the other: Exoticism in the promotion of literature from the Middle East and Asia. In M. Huang (Ed.), Beyond boundaries: East and West cross-cultural encounters (pp. 230-248). Cambridge Scholars Publishing.

Türk Dil Kurumu. (n.d.). Bahşiş. In Güncel Türkçe sözlük. Retrieved June 13, 2021, from https://sozluk.gov.tr

Ülsever, C. (2011). The murders at castletop (M. Akcanbaş, Trans.). Foremost Press.

Venuti, L. (1995). The translator's invisibility: A history of translation. Routledge. https://doi.org/10.4324/9780203360064

Watts, R. (2005). Packaging post/coloniality: The manufacture of literary identity in the Francophone world. Lexington Books. 